European Journal of Accounting, Auditing and Finance Research

Vol.8, No. 7, pp.97-120, July 2020

Published by ECRTD-UK

Print ISSN: 2053-4086(Print), Online ISSN: 2053-4094(Online)

\title{
EFFECT OF ENVIRONMENTAL COST ON PERFORMANCES OF QUOTED FIRMS IN SUB-SAHARAN AFRICA, 2007-2016
}

\author{
Steve Chijioke Nwaimo PhD \\ Gregory University Uturu, Abia State \\ drchijiokenwaimo@gmail.com
}

\begin{abstract}
The study examined the effect of environmental costs on performances of quoted firms in Sub Saharan Africa. The study adopted longitudinal/panel ex-post facto research design and random sampling technique while quantitative secondary data covering 2007 to 2016 were obtained for sixty-four extractive and industrial firms quoted in the Stock Exchanges of four SubSahara African countries namely South Africa, Nigeria, Ghana and Tanzania. The models for the study were estimated using Ordinary least square regression (OLS) built on panel data analysis. In the regional level analysis as well as in South Africa and Nigeria specific country analyses, the study revealed that environmental costs represented by employee health and safety, waste management and community development costs have no significant effect on return on capital employed, earnings per share and return on equity. The study showed that in Ghana, the predictor variables demonstrated significant effect on return on capital employed and return on equity while only waste management cost has significant effect on return on capital employed and return on equity in Tanzania. The implication of the preponderance of the findings, save for the aforementioned exceptions in Ghana and Tanzania, is that quoted firms in the region are yet to adequately indulge in environmental responsibility or their environmental engagements are not adequately captured and disclosed to the extent that can cause significant swings in the measures of firm performance. The implication of the exceptions found in Ghana and Tanzania is that of comparative improvement in environmental responsibilities, compliances and disclosures by quoted firms in the two countries. The study recommended among other things that firms in Sub Saharan Africa should give greater attention to environmental responsibility, cost recognition, classification and disclosures in the annual, integrated and sustainability reports.
\end{abstract}

KEY WORDS: environmental costs, employee health and safety, waste management, community development costs, performance, capital employed, return on equity, earnings per share

\section{INTRODUCTION}

Resources, services and supports provided by the environment for the existence of man and his activities are numerous and unavoidable. Specifically, the environment provides natural resources to production and consumption activities; absorbs waste emanating from production and consumption activities; supports life and other human endeavours. Environment is a contributor to both production and human welfare through the provision of resources, including space for human activity; waste absorption services such as neutralization, dispersion or recycling of wastes from human activity; environmental services such as the maintenance of a habitable biosphere, including the stratospheric ozone layer, climate stability and genetic diversity; and the provision 
European Journal of Accounting, Auditing and Finance Research

Vol.8, No. 7, pp.97-120, July 2020

Published by ECRTD-UK

Print ISSN: 2053-4086(Print), Online ISSN: 2053-4094(Online)

of services for human amenity, recreation and aesthetic appreciation (United Nations Integrated Environmental and Economic Accounting, 2003). Worthington (2012) and Association of Chartered Certified Accountants (2015) confirmed that environmental awareness by businesses of the environmental repercussions of their operations (products and services) has been growing. In the recent times, there has been an increased awareness of the interaction between firms and environment in which they operate, this enlightenment has been sharpened by concerns about resources depletion, resources scarcity, environmental degradation and the activities of these firms that lead to the depletion of the ozone layer and thereby causing an imbalance in the environmental system (Omodero, \& Ihendinihu, 2016).

Obviously, the interaction with the environment has implications and costs associated with it. According to (Duke, \& Kankpang, 2013), the constant interaction of organisms and plants with the environment result to negative and positive changes on both side and usually with long-lasting implications and consequences for the physical landscape. Man happens to be at the centre stage of environmental degradation. (Beredugo, 2014) confirmed that like all other living creatures, humans have clearly changed their environment, and they have done so generally on a grandeur scale than have all other species. Dutta and Bose (2008), concluded that the activities of man aimed at meeting man's numerous wants result to some consequences such as rural-urban migration, deforestation, desertification and emission of effluence and other wastes which have impacted negatively on the natural environment with these activities generating a variety of problems including soil, atmospheric, water and mouse pollution.

The environment is crucial for production, distribution and consumption of goods and services as well as incidental waste management. The production of goods and services relies on inputs from the environment that result to depletion of resources and the attendant implications on the natural environment. Production inputs like raw materials deplete the quantity of available natural resources with part of the inputs resulting to wastes that are subsequently returned to the environment. Wastes come in different forms and effects. One of the common effects of waste to the environment is pollution which occurs when wastes disrupt or change natural systems, including those that are important for human well-being such as air and water. According to (Pramanik, Shil, \& Das, 2007), the present civilization has involved man in varied activities, many of which generate waste with potential constituents, the ultimate of whose disposal lead to environmental pollution in many parts of the world and the magnitude of which has already reached an alarming level.

Environmental costs are central to environmental accounting and reporting. (Uwuigbe, \& Olayinka, 2011) described environmental cost as impacts incurred by society, an organisation or individual resulting from entities that affect environmental quality. Consequently, firms' performances and parameters for measuring them, have changed from owners' profit maximization to include environmental responsiveness. Failures and successes of firms are not going to be based only on the market acceptability of their products and services or the net returns on investment but also other parameters that question their responsibility and responsiveness to the environment in which they operate and depends on. For (Omodero, \& Ihendinihu, 2016), the success or failure of a company may be determined not only by the products or services it deals 
European Journal of Accounting, Auditing and Finance Research

Vol.8, No. 7, pp.97-120, July 2020

Published by ECRTD-UK

Print ISSN: 2053-4086(Print), Online ISSN: 2053-4094(Online)

with but also by the complexity of its environment. The implication of this is that the hitherto disconnect between the wellness or otherwise of firms and the consequences of their business operations on the environment is not going to be the case going forward. Firms are further adjudged not only on owners' profit maximization but also by their responsiveness and responsibility to the environment as well on the sustainability of the environment which is the ability of the environment to provide equivalent support and services to future generations.

Environmental costs can take different forms and this could be a function of the operational peculiarities of firms. Firms in explorative activities like oil exploration and mining activities are associated with oil spills, water pollution, air pollution, noise pollution, landscape degradation, employee health hazard, destruction of communal land and agricultural investments etc while industrial firms engaged in production of industrial goods will be faced with air pollution, noise pollution, employee health hazards.

Traditionally, firm performances have been measured predominantly as they affect shareholders benefits thereby ignoring the interest of the other stakeholders. Contemporarily, this narrowed perspective has changed and given way to broader stakeholders' consideration. Consequently, firm performances measurement should include all facets of performance indicators to satisfy the wider stakeholder considerations brought to bear in firm's activities and expectations by environmental engagements, externalities and responsiveness. In line with this, (Richard, Devinny, Yip, \& Johnson, 2009) opined that firm's performance encompasses three specific areas of shareholders return, financial and market performances. However, noteworthy is the fact that firm's market performance (which is measureable by share price, earnings per share, market value per share or market capitalization) is a function of and influenced by both financial performance and shareholders returns. This implies that firm's market performance is highly influenced by shareholders earning indices (dividend per share, dividend yield) and financial performance indices (Return on capital employed, Net profit margin, firm net worth etc). As a framework, this study relates proxies of financial, market and shareholder performances to disaggregated environmental costs to ascertain the extent to which the latter affect the performances of firms in Sub Saharan Africa. In doing this, the study adopted return on capital employed, earnings per share and return on equity as measures of financial, market and shareholders performances respectively while disaggregated community development (CD), employee health and safety (EHS) and waste management costs (WM) are the explanatory variables.

\section{Statement of Problem}

Prior empirical findings have inconclusively narrowed down the effect of environmental costs on firm performances resulting to controversies by varied schools of thoughts on the subject. According to (Horvathova, 2010), the inconclusive prior empirical findings of the relationship between environmental performance and firm performance have led to conflicting results due to the three competing schools of thoughts that exist recently in the field: that better environmental performance improves financial performance; the contrary that better performance does not improve financial performance and that which opine that there is no connection between environmental and financial performances. This forms a fundamental gap on which this study is anchored. Consequently, opinions have been strong and dominated between the classical school 
Vol.8, No. 7, pp.97-120, July 2020

Published by ECRTD-UK

Print ISSN: 2053-4086(Print), Online ISSN: 2053-4094(Online)

(proponents of negative effect) and the contemporary school (proponents of positive effect) on this aged dichotomy that these have given birth to postulations on the effect of environmental costs on firm performances. The classical proponent viewed all costs (including environmental costs) as reduction in profits with consequential negative effect, therefore, the basis of cost reduction strategies. For them, all manner of costs (including environmental costs) are inversely related to firm performance. (Amoako, Lord, \& Dixon, 2016). This is the bedrock of traditional accounting and reporting that also anchors cost minimization strategies and narrowed perspective on firm performances. Therefore, the divergent opinions on the subject with shortcomings and variances of prior empirical studies have necessitated a study to offer some improvements and to establish the effect of environmental costs on firm performances in Sub-Sahara African.

\section{Objectives of the Study}

The broad objective of the study is to examine the effect of environmental costs on performances of quoted firms in Sub Saharan Africa. Specifically, the objectives are:

1. To determine the effect of waste management, community development and employee health and safety costs on Return on Capital Employed of quoted firms in Sub Saharan Africa.

2. To explore the effect of waste management, community development and employee health and safety cost on Earnings per Share of quoted firms in Sub Saharan Africa.

3. To ascertain the effect of waste management, community development and employee health and safety costs on Return on Equity of quoted firms in Sub Saharan Africa.

4. In each of the four countries studied, to evaluate the respective effect of waste management, community development and employee health and safety costs on Return on Capital Employed, Earnings per Share and Return on Equity of quoted firms in Sub Saharan Africa.

\section{Statement of Hypotheses}

The following hypotheses were generated for this study:

$\mathrm{Ho}_{1}$ : Waste management, community development and employee health and safety costs have no significant effect on Return on Capital Employed of quoted firms in Sub Saharan Africa.

$\mathrm{Ho}_{2}$ : Waste management, community development and employee health and safety costs exact no significant effect on Earnings per Share of quoted firms in Sub Saharan Africa.

Ho3: Waste management, community development and employee health and safety costs do not exact significant effect on Return on Equity of quoted firms in Sub Saharan Africa

Ho4: In each of the four countries studied, waste management, community development and employee health and safety costs have no significant effect on Return on Capital Employed, Earnings per Share and Return on Equity of quoted firms in Sub Saharan Africa.

\section{REVIEW OF RELATED LITERATURE}

\section{Concept of Environmental cost}

The term environmental cost has been difficult to define. The difficulty lies in the fact that it incorporates the intangible and tangible costs; the challenge of ascertaining its burden and incidence and lastly because of the concept of externalities which are difficult to estimate or restrict to given geographical boundaries. Intangible costs are those with high level of difficulty in quantification and most times not immediately visible. In addition to the fact that the existence of 
European Journal of Accounting, Auditing and Finance Research

Vol.8, No. 7, pp.97-120, July 2020

Published by ECRTD-UK

Print ISSN: 2053-4086(Print), Online ISSN: 2053-4094(Online)

the intangibles cannot be clearly noticed at inception, valuation of intangibles is usually difficult resulting to estimations that are fraught with both complexities and subjectivity. The definition of environmental cost is made more difficult by its burden and incidence. For example, the cost of environmental degradation does not fall on those responsible for the degradation (that is, the firms whose operations result to degradation), but falls on the present and future generations of the society as a whole. Externality as well as its estimation difficulties further compound and complicate the definition of environmental costs. (Bartolacci, Paolini, Soverchia, \&Zigiotti,2016) In the light of this, (Betianu, 2005) therefore argued that the definition of environmental cost depends on utilization of information in a company and that environmental costs can include conventional costs (raw materials and energy costs with the environmental relevance), potentially hidden costs (costs which are captured by accounting system but then lose their identity in overheads), contingent costs (costs in a future time - contingent liabilities), and image and relationship costs. Therefore, environmental costs, on a generic perspective, can be defined as the implicit and explicit consequences of human and industrial activities on the environment. It has become necessary to incorporate explicit and implicit implications of human and industrial activities on the environment in the definitions of environmental cost to accommodate nonfinancial implications of actions or inactions of firms and to include the costs of things not done or costs that cannot be readily ascertained with respect to environmental degradation.

\section{Environmental Management Accounting (EMA)}

Some consciousnesses have evolved to ensure that firms take environmental matters more seriously. Environmental Management Accounting (EMA) is a designated area of accounting for firms to internally record and process environmental costs towards producing environmental reports that will meet firms' decisions regarding environmental degradation as well as proactive measure to forestall it. (Bassey, Sunday, \& Okon, 2013).This is separate from Financial Accounting and Management Accounting even though Environmental Management Accounting tremendously draws from both and contributes to them too. Judging from the difficulty of assigning a universally accepted definition for environmental costs, Environmental Management Accounting also has no single and universally accepted definition. The (International Federation of Accountants, 2005) in her Statement of Management Accounting Concepts defined Environmental Management Accounting as the management of environmental and economic performance through the development and implementation of appropriate environment-related accounting systems and practices. While this may include reporting and auditing in some firms, environmental management accounting typically involves life-cycle costing, full-cost accounting, benefits assessments, and strategic planning for environmental management. The scope of Environment Management Accounting therefore begins from the scope of environmental costs because the former flows to catch up, analyse, present and report the latter. Environmental costs varies from disposal costs, to investment costs on environmental remediation and other externality costs which are usually outside the reach of the firm and cannot be easily restricted to time. Demissie, 2014).

Environmental Management Accounting is broadly defined to be the identification, collection, analysis and use of two types of information for internal decision making: (i) physical information on the use, flow and destinies of energy, water and materials (including wastes) and (ii) monetary 
European Journal of Accounting, Auditing and Finance Research

Vol.8, No. 7, pp.97-120, July 2020

Published by ECRTD-UK

Print ISSN: 2053-4086(Print), Online ISSN: 2053-4094(Online)

information on environment-related costs, earnings and savings (United Nation Expert Working Group on Environmental Management Accounting , 2001). The imperative of Environmental Management Accounting to a great extent is on the observed shortcomings of the conventional accounting which lumps environmental costs together in general overheads and as such suffocates the clarity of transactions and necessary management decisions on environmental actions. In firms' financial accounting structures, environmental costs are indistinctively classified as such in the charts of accounts resulting to generic and wrong classifications thereby leading to loss of identity of the cost in overheads that translate to poor decisions on environmental matters. Consequently, access to financial information by environmental managers and experts on environmental costs is also restricted and when made available, there is difficulty of separating environmental costs from the general overheads.

\section{Concept of Environmental Risk and Environmental Responsibility}

The entire society is at risk; Sub Saharan Africa is at a greater risk. The risk includes that of environmental degradation which is caused by man in his quest for existence, ultimate present or future incidence and effect of the risk on human generation. This risk by all measure is enormous. The time frame of the risk includes those obviously facing the present generation that occupy the environment and those that affect the future generation that will depend on the environment for equivalent support services (which is, the sustainability risk). (Moneva, \& Ortas, 2010)

Sustainability risk is the tendency that the environment cannot adequately sustain the future generations as a result of present degradation. (Wingard, 2001) captured this risk from the perspective of ecological crisis and argued that the related problems of a growing world population, depletion of natural resources and pollution have led to an ecological crisis that is endangering natural systems of which humans are part. The historical foundation of sustainability risk dates back to the evolution of man but the contemporary environmentalists attribute this anomaly to the westernization culture which through the instrumentality of colonization has swept over the whole world. Similar to the westernization proponent of sustainability risk, (Schaltegger, Gibassier, \& Zvezdov, 2013) averred that many contemporary environmentalists have accused the Judeo-Christian tradition of containing the historical roots of our ecological crisis. (Singapurwoko, \& El-Wahid, 2011) therefore concluded that the western view of life can be traced back to Judeo-Christian times and is founded in the assumptions that humans have the obligation to master and manipulate nature to their benefit and that the natural environment has unlimited possibilities for exploitation.

Environmental responsibility is an aspect of corporate social responsibility and measures the extent to which a firm indulge in wholesome or unwholesome practices to protect the environment or otherwise. (Wingard, 2001) posits that corporate social responsibility is the obligation of decision makers to take actions which protect and improve the environment as a whole, along with their own interests. It is the obligation of both business and society (stakeholders) to take proper legal, moral-ethical, and philanthropic actions. It has been widely argued that the environment and employees are facets of social responsibility and as such environmental responsibility can be defined as the social responsibility of enterprises which encompasses the attitude of enterprises to do business in accordance with the ethical and moral standards acceptable to society. Social 
European Journal of Accounting, Auditing and Finance Research

Vol.8, No. 7, pp.97-120, July 2020

Published by ECRTD-UK

Print ISSN: 2053-4086(Print), Online ISSN: 2053-4094(Online)

responsibility is the moral but fast becoming statutory duty of both business and society (stakeholders) to take proper legal, moral-ethical, and philanthropic actions that will protect and improve the welfare of both society and business as a whole (Wingard, 2001). These responsibilities must be accomplished by all parties within an economic framework and capabilities which are the bedrock for the accomplishment of the responsibilities. Judging from the above and given that environmental responsibility draws from corporate social responsibility, a firm is considered environmentally responsible when it first considers the legal, ethical, moral actions in its operations and business undertakings with the ultimate objective of ensuring that the environment is not left worse-off that it fails to sustain the present and future generations. (Wingard, 2001) therefore considers environmental responsibility as manifesting itself in a strategy that the management of a firm decides to follow relating to the level of environmental performance it wishes to attain; the levels ranging from mere compliance with legal requirements to following sustainable development principles. Though environmental responsibility is a strategy, planning the strategy for a firm's environment-related activities is a function of not only where the company is at present but also where the company intends to be in terms of its environmental performance.

\section{Concepts of Eco-Efficiency and Sustainability}

Eco-efficiency relates to the most efficient use of resources with the least possible damage to the environment, e.g by recycling materials in products, use of raw materials and of energy to convert the raw materials (Wingard, 2001). At the heart of eco-efficiency and environmental responsibility is the concept of sustainability. After taking due considerations to operate eco-efficiently and environmentally responsible, further and conscious appraisal must be carried out to ascertain that what has been done in terms of eco-efficiency and environmental responsibility translate to good results in terms of assurances that future generations receive equivalent benefit and due share from the same environment.

Sustainability is more to development than growth in the sense of realizing or returning the potential inherent in the eco system which is the subject of consideration unlike growth that relates more to physical increase. In a well thought view of a renowned economist, (Wingard, \& Vorster, 2001), to grow means 'to increase naturally in size by the addition of material through assimilation or accretion'. He further stressed that to develop means 'to expand or realize the potentialities of; to bring gradually to a fuller, or better state. When something grows it gets bigger but when something develops it gets different.Therefore, the earth's ecosystem develops (evolves), but it does not grow. Its subsystem, the economy, must eventually stop growing, but can continue to develop. The term sustainable development therefore makes sense for the economy only if it is understood as development without growth.

\section{Costs and Benefits of Environmental Responsibility}

Environmental responsibility is not without some costs and benefits. The benefits are the gains derived or derivable by firms as a result of being responsive to environmental issues and for ranking high in environmental performances. The benefits are the opportunity cost of actions taken to remedy the environment and in being responsible. Benefits can be explicit and/or implicit, monetary and/or non monetary, short run and in most cases long run. Environmental performance 
European Journal of Accounting, Auditing and Finance Research

Vol.8, No. 7, pp.97-120, July 2020

Published by ECRTD-UK

Print ISSN: 2053-4086(Print), Online ISSN: 2053-4094(Online)

may affect revenues (Earnhart \& Lizal, 2010). Benefits from environmental responsiveness may come in various ways and varied channels. For example, perception of customers may change favorably for environmentally responsible firms and this may snowball into increase patronage for products offered for sale irrespective of high price disparity when compared with products of non complying firms and may result to positive revenue relationship. Justifiably, this may be anchored on the willingness of the customers to pay or buy more of environmentally friendly products (green products). Thus, a firm is able to increase its revenues by reducing its environmental impact in order to sell green products. Environmental responsibility may be an investment strategy targeted for long run benefit of the firm. Firms may adopt greater investment in the environment as strategy for better and visible placement in a complicated and crowded market. (Ambec, Stefan, \& Lanoie, 2008) confirmed this and identified environmental responsibility as a differentiation strategy to exploit niches in environmentally conscious market segments.

\section{Postulations on the Nexus of Environmental and Firm Performances}

Scholars are divided in their opinions and postulations as to the directions which environmental performance (encapsulated in firms' environmental responsibility) drive firm performances. The classical school of thought has persistently classified environmental performance as additional cost on the firm whose bottom line implication is a reduction in firm's profitability as well as in other performance measures. Investments in environmental friendly technologies are either seen as not necessary, incurrence of additional heavy cost or as having no accruable benefit associated with it. Poor compliance to environmental standards which globally is yet evolving from voluntary compliance to quasi- mandatory compliance is an offshoot of the classical thought that perceives environmental investment and cost outlay as not compelling and as such not key to the firms' business objective. (Makori, \& Jagongo, 2013). It follows therefore that host communities and environmental stakeholders who are affected by firms' operations and associated degradation are neglected. Consequently, environmental stakeholders and host communities are rarely considered as important stakeholders in business decisions resulting to neglect of the consequences of business operations and the externalities caused to the environment and host communities. Scholars have followed this school to canvass for lack of positive connectivity between environmental performance and firm performance. The traditional school of thought views environmental expenditures, whether on end-of-pipe treatment or pollution prevention efforts, as a drain on firms' resources. (Filbeck, \& Gorman, 2004) argued that in contrast to these enhancements to cost minimization, complex pollution-reducing devices and processes may reduce overall productive efficiency thus, raising production costs. From a generic perspective, this school argued that investments in environmentally responsible behavior may drag down financial performance because resources are being committed to what may appear as an ostensibly non-productive use. Specifically, environmentally responsible business decisions may limit a firm's strategic alternatives, thus, driving down revenues and driving up costs. For example, a firm may decide not to pursue certain product lines or avoid plant relocations and investment opportunities in certain locations.

On the other hand, the contemporary school has a divergent view point anchored on value relevance of environmental responsibility to firms' performance. The school constituting mainly of environmentalists sees environmental performance as key to business as well as its successes. 
European Journal of Accounting, Auditing and Finance Research

Vol.8, No. 7, pp.97-120, July 2020

Published by ECRTD-UK

Print ISSN: 2053-4086(Print), Online ISSN: 2053-4094(Online)

Accordingly, it becomes part of the critical business decision and strategies to indulge in environmentally friendly investments that have positive trade off between benefits and costs of such investments. Many scholars have followed this thought with strong indications that environmental performances have negative impact on cost, positive impact on revenue and firms' bottom line. Contemporary scholars have indicated strong direct and positive links between environmental performance and performance of firms. In this line, (Wingard, 2001) posited that a major costs faced by most manufacturers is waste disposal and especially hazardous waste disposal and further asserted that an environmentally responsible firm may be able to reduce these costs along with the liability associated with them. It seems rational and reasonable to believe that it would cost less to prevent pollution rather than clean up after it (Wingard, 2001). (Neely, 2015) argued that a total quality environmental management program can help organizations comply with increasingly stringent environmental regulations; reduce manufacturing costs by lowering the tangible costs of chemical disposal, waste treatment and licensing and laboratory fees.

\section{Historical Perspective of Environmental Crises in Sub Saharan Africa}

Historically and prior to the advert of colonialism, the management and conversation of the environment and natural resources in Sub Saharan Africa was largely a community responsibility. The survival of the community depended on extensive and very intimate knowledge and sustenance use of land, forests and wildlife, resources (UNEP, 2000). On his account of the management of the environment, (Ogbe, 2003) narrated that those living in large dry lands in the savannah belt, for example, led pastoral lifestyles and migrated with their families and livestock in response to recurrent droughts and other environmental challenges. Those in the rain forest belt developed agricultural systems that are adapted to the fragile nature of the soil while retaining the protective features of the forest canopy virtually undisturbed. Though undocumented as standard principles and practices, the traditional knowledge and culture of these communities in addition to related conservation practices and principles were generationally enhanced and passed on by successive generations, including social taboos and community sanctions that were imposed on those who violated the norms. Wars were fought between communities and tribes to maintain the integrity of their domain and prevent unauthorized access to their natural resources (Ogbe, 2003). Prior to the European inversion of Africa, in the countries of the North, the availability of cheap agricultural products from the south provided a source of industrial feedstock for their impressive economic development (Ogbe 2003).

During the colonial period, the European powers imported and imposed laws and regulations which undermined and replaced the traditional community-based approach to conservation and sustainable use of natural resources. This paradigm shift arising from colonization and clamp down on African resources also frosted a development pattern focused mainly on economic growth, with the export of key commodities and natural resources given priority over subsistence agriculture and internal food security (Ogbe 2006). Contemporarily, it is postulated that colonialism was targeted at the abundant natural resources of the African continent not for African emancipation as claimed by the colonialist. This contemporary perspective has given rise to the concept of neocolonialism which in principle and practice is an extension of economic colonization years after the dismantling of political colonialism. It is the aforementioned paradigm shift from African traditional and environmental conservation to colonialism and developmental pattern of export of 
European Journal of Accounting, Auditing and Finance Research

Vol.8, No. 7, pp.97-120, July 2020

Published by ECRTD-UK

Print ISSN: 2053-4086(Print), Online ISSN: 2053-4094(Online)

raw materials that gave rise to the need for mass production or exploitation of natural resources in Sub Saharan Africa to meet the growing need of the European countries. It is not surprising, however, that this was the beginning of mechanizations aimed at easing off exploitation process for mass production that inadvertently resulted to environmental degradations in the sub region. Colonialism therefore was a helpless strategic mistake which created many problems for African countries including unrealistic dependence on commodities processed in world trade system dominated by major industrialized countries and the inherent vulnerability to fluctuations in the prices of unprocessed natural resources. The situation was helpless for the poor Africans given that colonialism was foist on them with all manners of forces and deception and Africans saw themselves engulfed in helpless colonialism which their level of emancipation never endowed them to resist.

\section{Firms Performance and Measurement}

(Richard, et.al., 2009) averred that firms' performance encompasses three specific areas that comprise financial performance, market performance and shareholders returns. In this study, firm performance is the dependent variable and shall be considered from the aforementioned three components of firms' performance measurement. The study regresses that the disaggregated components of environmental costs on the proxies of the three components of firms' performance to ascertain the relationship between the independent and dependent variables. Firm performance measurement is a process and also generic. (Al-Matari, Al-Swidi, \& Fadzil, 2014) confirmed that firms' performance is a generic process of measuring the efficiency and effectiveness of the actions and activities of firms. Firm performance is an appraisal of the actual results of operations and activities of firms based on pre-determined set of goals and objectives. It is an internal mechanism set by firms to judge themselves, their goals and objectives against their actual results on the basis of which any external due diligence if carried out on the firms can confirm the authenticity or otherwise of the firms' success. (Appiah, Du, \& Boamah, 2017) asserted that the subject of corporate performance has received significant attention from scholars in the various areas of business and strategic management. However, finding useful components of performance measures is a relevant area for research and a major difficulty is defining the appropriate components and showing whether the interpretations that result are reasonable and applicable elsewhere (Arafat, Warokka, \& Dewi, 2012).

\section{Empirical Review \\ Studies in South Africa}

(Wingard, 2001) studied financial performance of environmentally responsible South African listed companies. The study utilized annual financial statements for active companies listed in Jonesburg Stock Exchange for periods ranging from 1994 to 1998 to ascertain the correlation between environmental responsibility and financial performance. The study found a slim positive correlation between financial performance and environmental responsibility. (Wingard and Vorster, 2001) carried out an in-depth examination of the financial performance of environmentally responsible South African listed companies. Using correlation analysis, they argued that a positive relationship existed between environmental responsibility and financial performance of South African listed companies. (Delmas \& Nairn-Birch, 2010) examined the impact of greenhouse gas emissions (ghg) on firm financial performance. Interestingly, their 
European Journal of Accounting, Auditing and Finance Research

Vol.8, No. 7, pp.97-120, July 2020

Published by ECRTD-UK

Print ISSN: 2053-4086(Print), Online ISSN: 2053-4094(Online)

findings indicated that increasing carbon emissions resulted in a positive impact on firm financial performance when employing accounting based measures of financial performance, while the same linkage was negative when using market-based measures of firm financial performance. (Oberholzer \& Prinsloo, 2011) carried out study on South African gold mining firms. Using multiple environmental performance proxies such as green house emission, water usage and energy usage as independent variables, the study revealed that gold mining firms did not realize economic gain from efficient use of the environmental variables. Focusing on South African mining firms, (Nyirenda, Ngwakwe, \& Ambe, 2013) carried out a study on environmental management practices and firm performance using shareholders return measure of firm performance(Return on Equity) as proxy. The result from the study revealed lack of significant relationship between the dependent and independent variables.

\section{Studies in Nigeria}

Related empirical evidences were obtained from Nigeria. Drawing evidence from sixty Nigerian manufacturing companies, (Ngwakwe, 2008) studied environmental responsibility and firm performance. The study used only Return on Total Assets (ROTA) as proxy for financial performance and disaggregated environmental responsibility into employee health and safety (EHS), waste management (WM), and community development (CD) and revealed that environmental responsibility affect financial performance in Nigeria. The study further revealed that the sustainable practices of the 'responsible' firms are significantly related with firm performance and sustainable practices are inversely related with fines and penalties. The study concluded that within the Nigerian setting at least, sustainability affects corporate performance. (Oti, Effiong, \& Tiesieh, 2012) conducted a study on environmental costs and implication on return on investment for manufacturing firms in Nigeria and revealed a positive relationship between return on investment and environmental costs.

(Peter, Sunday, \& Tapang, 2012) studied environmental costs and its implication on the returns on investment with finding that shows that investment in social and environmental responsibilities are related to improved return on investment. From disclosure angle, (Oba, Fodio, \& Soje, 2012) investigated the value relevance of environmental responsibility information disclosure using evidence from eighteen (18) environmentally sensitive listed firms in Nigerian for the year 20052009. The study revealed a positive and significant relationship between quality of environmental disclosure and financial performance and vice versa. (Adediran, \& Alade, 2013) studied the impact of environmental costs on corporate performance. With secondary data collected from annual reports of fourteen companies randomly selected and analyzed using multiple regression analysis, it was revealed that a significant negative relationship exist between environmental costs and Return on Capital Employed and Earnings per Share.

Drawing research evidences from oil companies in Niger Delta Nigeria (Ifurueze, Etale, \& Bingilar, 2013), conducted a study on the impact of environmental cost on corporate performance. The study which applied multiple regression analysis investigated the possible relationship between corporate performance and three selected indicators of sustainable business practices: community development cost (CDC), waste management cost (WMC) and employee health and safety cost (EHSC). The study revealed that sustainable business practices and corporate 
European Journal of Accounting, Auditing and Finance Research

Vol.8, No. 7, pp.97-120, July 2020

Published by ECRTD-UK

Print ISSN: 2053-4086(Print), Online ISSN: 2053-4094(Online)

performance are significantly related given that sustainability may be a possible tool for corporate conflict resolution as evidenced in the reduction of fines, penalties and compensations paid to host communities of oil companies. Therefore, the researchers recommended that the management of oil companies in the Niger Delta States of Nigeria should develop a well articulated environmental costing system in order to guarantee a conflict free corporate atmosphere needed by managers and workers for maximum productivity and eventually improve corporate performance.

(Arong, Ezugwu, \& Egbere (2014) conducted a study on environmental cost management and profitability of oil sector in Nigeria. Using multiple regressions to analyze data obtained from the Central Bank of Nigeria (CBN) that covered 2004 to 2013, the study revealed that there exist a significant relationship between influence of environmental cost management and the profitability of oil sector in Nigeria. Extending to corporate social responsibility, (Osisioma, Nzewi, \& Okoye, 2015), carried out a study on corporate social responsibility and performance of selected firms in Nigeria and revealed a significant relationship between social responsibility cost and corporate profitability. The study concluded that social responsibility was vital to organizational performance and recommended that firms in Nigeria should increase their commitment to social responsibility by setting aside substantial amount of their income to social responsibility programmes. Also on corporate social responsibility and drawing evidence from selected listed firms in the Nigeria Stock Exchange, (Omodero, et. al., 2016) carried out a study on impact of environmental and corporate social responsibility accounting on organizational financial performance. Using five years' time series data of selected companies quoted in the Nigerian Stock Exchange, the study revealed that oil companies' CSR expenditure cannot be compared with the destructive effect of their activities in the host communities. Similarly, (Agbiogwu, Ihendinihu, \& Okafor, 2016) conducted a study on the impact of environmental and social costs on performance of manufacturing companies in Nigeria. Adopting non-experimental design for 2014 data of ten randomly selected companies, the study found out that environmental and social costs significantly affect net profit margin, earnings per share and return on capital employed. (Okoye, \& Adeniyi, 2017), though specifically on a disaggregated cost (environmental protection cost) varied slightly into a study of the effect of environmental protection cost on product price in Nigerian brewery industry. The study discovered that there was negative relationship between environmental regulatory cost and product pricing decision.

\section{Studies in Ghana}

(Arafat, et. al., 2012) conducted a study on environmental costs and firm performances. Using descriptive analysis, the study revealed an inverse $U$ shape relationship which commenced on a positive trend and thereafter nose-dive into a negative relationship. (Appiah, et. al., 2017) did an empirical study of the effect of environmental performance on firms' performance. The study applied total cash cost and capital expenditure as proxies for firm performances and energy consumption, water consumption and carbon emission as proxies for environmental performance. The study revealed mixed relationships between the variables.

\section{Studies in Tanzania}

(Daniel, 2013) carried out a study on effect of Environmental regulations on financial performance of manufacturing companies in Tanzania. The study used regression analysis with a sample of five 
European Journal of Accounting, Auditing and Finance Research

Vol.8, No. 7, pp.97-120, July 2020

Published by ECRTD-UK

Print ISSN: 2053-4086(Print), Online ISSN: 2053-4094(Online)

(5) selected listed manufacturing companies and found out that environmental compliance has no significant effect on the financial performance of listed financial companies in Tanzania. Extending to corporate social responsibility and drawing from Tanzania perspective, (Isanzu, \& Fengju, 2016) conducted a study on impact of corporate social responsibility on firms' financial performance. The study which adopted content analysis on one hundred and one companies for three years period covering 2010 to 2012 revealed that return on assets(ROA) and return on investment(ROI) of companies that engage in corporate social responsibility are significantly different from those that do not

\section{METHODOLOGY}

\section{Research Design}

A longitudinal/panel ex-post facto research design was adopted to examine the effect of environmental cost on performance of quoted firms in Sub-Saharan Africa

\section{Population of Study}

The population of the study is drawn from four countries randomly selected from the pool of fortysix countries in Sub Saharan Africa as follows: Nigeria, Ghana, South Africa and Tanzania. As at the end of December 2016, the Stock Exchanges of South Africa, Nigeria, Ghana and Tanzania had four hundred (400), one hundred and seventy-five (175), forty-two (42) and twenty-five (25) quoted firms respectively. This gives a total of six hundred and forty (642) quoted firms in the four selected countries in Sub Saharan Africa

\section{Sample Size and Sampling Techniques}

Through random sampling and Taro Yamane formula a sample size of 64 was derived and Using random sampling, the study selected forty (40), eighteen (18), four (4) and two (2) firms from South Africa, Nigeria, Ghana and Tanzania respectively. The list of the sixty-four selected firms used in the study is in appendices.

Table 1: Summary of Quoted Firms in Population and Sample

\begin{tabular}{llllll}
\hline S/N & Countries & $\begin{array}{l}\text { Number of firms } \\
\text { in } \\
\text { population }\end{array}$ & $\begin{array}{r}\text { Number of firms in high } \\
\text { initial } \\
\text { perntry }\end{array}$ & $\begin{array}{l}\text { Number of firms } \\
\text { sensitive areas per } \\
\text { country. }\end{array}$ & $\begin{array}{l}\text { selected to constitute } \\
\text { the sample per } \\
\text { country }\end{array}$ \\
\hline 1 & South & 400 & 70 & 40 \\
& Africa & & & 18 \\
3 & Nigeria & 175 & 31 & 4 \\
4 & Ghana & 42 & 5 & 2 \\
& Tanzania & 25 & 6 & 64 \\
\hline
\end{tabular}

Source: Observed and derived by this study 2019 
European Journal of Accounting, Auditing and Finance Research

Vol.8, No. 7, pp.97-120, July 2020

Published by ECRTD-UK

Print ISSN: 2053-4086(Print), Online ISSN: 2053-4094(Online)

\section{Model Specification}

The generic models of the study described above are as follows:

$\mathrm{ROCE}=\mathrm{f}(\mathrm{EHSC}+\mathrm{CDC}+\mathrm{WMC})$

$\mathrm{ROE}=\mathrm{f}(\mathrm{EHSC}+\mathrm{CDC}+\mathrm{WMC})$

Representing the above in matrix form,

$\mathrm{Y}=\beta \mathrm{X}_{1}$

And in Econometric format:

$\begin{array}{lll}\operatorname{ROCE}_{\mathrm{ssa}}= & \beta_{0}+\beta_{1} \mathrm{EHSC}_{\mathrm{ssa}}+\beta_{2} \mathrm{CDC}_{\mathrm{ssa}}+\beta_{2} \mathrm{WMC}_{\mathrm{ssa}}+\mu & 4 \\ \mathrm{EPS}_{\mathrm{ssa}}=\beta_{0}+\beta_{1} \mathrm{EHSC}_{\mathrm{ssa}}+\beta_{2} \mathrm{CDC}_{\mathrm{ssa}}+\beta_{3} \mathrm{WMc}_{\mathrm{ssa}}+\mu & 5 \\ \mathrm{ROE}_{\mathrm{ssa}}=\beta_{0}+\beta_{1} \mathrm{EHSc}_{\mathrm{ssa}}+\beta_{2} \mathrm{CDc}_{\mathrm{ssa}}+\beta_{3} \mathrm{WMc}_{\mathrm{ssa}}+\mu & 6\end{array}$

\section{Method of Data Analysis}

The Ordinary Least Square (OLS) technique built in panel data analysis was used to estimate the models. Regression analysis is basically concerned with the study of the dependence of one variable (dependent variable) on one or more other explanatory or independent variables (regressors)

\section{Data Presentation and Analysis}

The mean data of the selected firm as computed by E-views 9.0 software via the criteria of Mean Plus SD Bound are detailed in this sub-section. The data used for the analysis were drawn from annual reports of selected firms spanning from 2007 to 2016. The average data on return on capital employed, earnings per share, return on equity, waste management cost, community development cost and employee and health safety cost are presented in Table 2.

Table 2: Average Data on Return on Capital Employed, Earnings per Share, Return on Equity, Waste Management Cost, Community Development Cost and Employee and Health Safety Cost from 2007 to 2016

\begin{tabular}{|c|c|c|c|c|c|c|}
\hline Year & $\begin{array}{l}\text { Return on } \\
\text { Capital } \\
\text { Employed }(\%)\end{array}$ & $\begin{array}{l}\text { Earnings } \\
\text { per Share }\end{array}$ & $\begin{array}{l}\text { Return on } \\
\text { Equity }(\%)\end{array}$ & $\begin{array}{l}\text { Waste } \\
\text { Management } \\
\text { Cost }\end{array}$ & $\begin{array}{l}\text { Community } \\
\text { Development } \\
\text { Cost }\end{array}$ & $\begin{array}{l}\text { Employee and } \\
\text { Health Safety } \\
\text { Cost }\end{array}$ \\
\hline 2007 & 2.60 & 2597 & 4.60 & 109.00 & 90.00 & 105.00 \\
\hline 2008 & 3.10 & 4200 & 6.50 & 78.00 & 119.00 & 109.00 \\
\hline 2009 & 16.60 & 5404 & 3.70 & 172.00 & 177.00 & 165.00 \\
\hline 2010 & -5.60 & 2723 & -8.90 & 169.00 & 230.00 & 175.00 \\
\hline 2011 & 0.90 & 2447 & -3.00 & 125.00 & 202.00 & 143.00 \\
\hline 2012 & 5.80 & 2317 & 9.50 & 96.00 & 261.00 & 143.00 \\
\hline 2013 & 0.20 & 1670 & 0.80 & 98.00 & 275.00 & 154.00 \\
\hline 2014 & 0.70 & 1720 & 1.80 & 110.00 & 257.00 & 139.00 \\
\hline 2015 & -4.50 & -371 & -10.90 & 121.00 & 229.00 & 141.00 \\
\hline 2016 & -1.70 & 1093 & -2.90 & 112.00 & 235.00 & 122.00 \\
\hline
\end{tabular}

Source: Annual Reports of selected quoted firms from 2007 to 2016; and output data from e-views 9.0.(2019) 
European Journal of Accounting, Auditing and Finance Research

Vol.8, No. 7, pp.97-120, July 2020

Published by ECRTD-UK

Print ISSN: 2053-4086(Print), Online ISSN: 2053-4094(Online)

\section{Trend in Environmental Cost \\ Waste Management Cost}

Waste management cost was 109.00 in 2007 , and reduced to 96.00 by the end of 2012 . The waste management cost of quoted firms in Sub-Saharan Africa continued to decline from 2013 to 2016. From 2007 to 2016, as shown in Table 2, Fig. 1 and 2, waste management cost of quoted firms in Sub-Saharan Africa gradually rose, though with marginal fluctuation from 109.00 in 2007 to 112.00 in 2016.

\section{Community Development Cost}

Community development cost was approximated to 90.0 in 2007 but increased to 202.00 in 2011. From 2007 to 2011, community development cost ranged from 90.00 to 202.00. It increased to 261.00 in 2012 but reduced to 235.00 in 2016. The trend in community development cost of listed firms in Sub-Saharan Africa is shown in fig. 3 and 4.

\section{Employees Health and Safety Cost}

Employees health and safety cost was approximated to 105.00 in 2007 which appreciated to 261.00 in 2012. From 2007 to 2011, employees' health and safety cost ranged from 105.00 to 143.00 . However, there was a reduction in 2016 as employees' health and safety cost was valued at 122.00. The trend in employees' health and safety cost of selected quoted firms in Sub-Saharan Africa is shown in fig. 5 and 6

\section{Test of Hypothesis}

Hypothesis Decision Criteria: If the p-value of F-statistic in granger causality test is less than 0.05, the null hypothesis is rejected. On the other hand, if the p-value of F-statistic in granger causality test is greater than 0.05 , the null hypothesis is accepted

Table 3: Result of Test of Hypotheses

\begin{tabular}{|c|c|c|c|c|}
\hline Hypothesis & Variables & P-Value & F-Stat. & Decision \\
\hline \multirow[t]{4}{*}{ Hypothesis 1} & $\mathrm{ROCE} \rightarrow \mathrm{WMC}, \mathrm{CDC}, \mathrm{EHSC}$ & & & \\
\hline & WMC & 0.12809 & 0.7206 & Accept $\mathrm{H}_{0}$ \\
\hline & $\mathrm{CDC}$ & 0.01684 & 0.8968 & Accept $\mathrm{H}_{0}$ \\
\hline & EHSC & 0.05325 & 0.8176 & Accept $\mathrm{H}_{0}$ \\
\hline \multirow[t]{4}{*}{ Hypothesis 2} & $\mathrm{EPS} \rightarrow \mathrm{WMC}, \mathrm{CDC}, \mathrm{EHSC}$ & & & \\
\hline & WMC & 0.66723 & 0.5136 & Accept $\mathrm{H}_{0}$ \\
\hline & $\mathrm{CDC}$ & 0.33091 & 0.7184 & Accept $\mathrm{H}_{0}$ \\
\hline & EHSC & 0.18730 & 0.8293 & Accept $\mathrm{H}_{0}$ \\
\hline \multirow[t]{4}{*}{ Hypothesis 3} & $\mathrm{ROE} \rightarrow \mathrm{WMC}, \mathrm{CDC}, \mathrm{EHSC}$ & & & \\
\hline & WMC & 0.70149 & 0.4963 & Accept $\mathrm{H}_{0}$ \\
\hline & $\mathrm{CDC}$ & 0.29694 & 0.7436 & Accept $\mathrm{H}_{0}$ \\
\hline & EHSC & 1.46220 & 0.2327 & Accept $\mathrm{H}_{0}$ \\
\hline
\end{tabular}

Source: Granger Causality Analysis

Table 3 shows the acceptance of the three null hypotheses as the p-vales of the f-statistics are greater than 0.05 (insignificant at 5\% significance level).

Table 4: Result of Test of Hypotheses 
European Journal of Accounting, Auditing and Finance Research

Vol.8, No. 7, pp.97-120, July 2020

Published by ECRTD-UK

Print ISSN: 2053-4086(Print), Online ISSN: 2053-4094(Online)

Hypothesis 4

\begin{tabular}{llccl}
\hline Hypothesis & Variables & P-Value & F-Stat. & Decision \\
\hline $\begin{array}{l}\text { South Africa } \\
\text { Hypothesis } \\
4(1)\end{array}$ & & & & \\
& ROCE $\rightarrow$ WMC, CDC, EHSC & & & \\
& WMC & 0.68326 & 0.5057 & Accept $\mathrm{H}_{0}$ \\
& CDC & 0.34309 & 0.7098 & $\begin{array}{l}\text { Accept } \mathrm{H}_{0} \\
\text { Accept } \mathrm{H}_{0}\end{array}$ \\
& EHSC & 0.94563 & 0.3995 & \\
Hypothesis & & & & \\
& EPS $\rightarrow$ WMC, CDC, EHSC & & & \\
& WMC & 0.62521 & 0.5358 & Accept $\mathrm{H}_{0}$ \\
& CDC & 0.21089 & 0.8100 & Accept $\mathrm{H}_{0}$ \\
& EHSC & 0.07071 & 0.9318 & Accept $\mathrm{H}_{0}$ \\
Hypothesis & & & & \\
$4(3)$ & ROE $\rightarrow$ WMC, CDC, EHSC & & & \\
& WMC & 0.63053 & 0.5330 & Accept $\mathrm{H}_{0}$ \\
& CDC & 0.35878 & 0.6988 & Accept $\mathrm{H}_{0}$ \\
& EHSC & 1.33928 & 0.2635 & Accept $\mathrm{H}_{0}$ \\
\hline
\end{tabular}

Nigeria

\begin{tabular}{lllll}
\hline $\begin{array}{l}\text { Hypothesis } \\
4(1)\end{array}$ & ROCE $\rightarrow$ WMC, CDC, EHSC & & & \\
& WMC & 0.45407 & 0.6360 & Accept $\mathrm{H}_{0}$ \\
& CDC & 0.07142 & 0.9311 & $\begin{array}{l}\text { Accept } \mathrm{H}_{0} \\
\text { Accept } \mathrm{H}_{0}\end{array}$ \\
Hypothesis & EHSC & 0.04059 & 0.9602 & \\
$4(2)$ & EPS $\rightarrow$ WMC, CDC, EHSC & & & \\
& WMC & 0.73937 & 0.4793 & Accept $\mathrm{H}_{0}$ \\
& CDC & 2.77829 & 0.0656 & Accept $\mathrm{H}_{0}$ \\
& EHSC & 0.72604 & 0.4856 & Accept $\mathrm{H}_{0}$ \\
Hypothesis & & & & \\
& ROE $\rightarrow$ WMC, CDC, EHSC & & & \\
& WMC & 0.94187 & 0.3924 & Accept $\mathrm{H}_{0}$ \\
& CDC & 0.12208 & 0.8852 & Accept $\mathrm{H}_{0}$ \\
& EHSC & 2.05906 & 0.1314 & Accept $\mathrm{H}_{0}$ \\
\hline
\end{tabular}

Ghana

\begin{tabular}{lllll}
\hline $\begin{array}{l}\text { Hypothesis } \\
4(1)\end{array}$ & ROCE $\rightarrow$ WMC, CDC, EHSC & & & \\
& WMC & 4.00224 & 0.0300 & Reject $\mathrm{H}_{0}$ \\
& CDC & 5.93207 & 0.0073 & $\begin{array}{l}\text { Reject } \mathrm{H}_{0} \\
\text { Reject } \mathrm{H}_{0}\end{array}$ \\
$\begin{array}{l}\text { Hypothesis } \\
4(2)\end{array}$ & EHSC & 4.36301 & 0.0228 & \\
& EPS $\rightarrow$ WMC, CDC, EHSC & & & \\
& WMC & 2.02190 & 0.1520 & Accept $\mathrm{H}_{0}$ \\
& CDC & 0.13881 & 0.8710 & Accept $\mathrm{H}_{0}$ \\
Hypothesis & EHSC & 0.09847 & 0.9065 & Accept $\mathrm{H}_{0}$ \\
$4(3)$ & ROE $\rightarrow$ WMC, CDC, EHSC & & & \\
& WMC & 6.74926 & 0.0042 & Reject $\mathrm{H}_{0}$ \\
& CDC & 7.00187 & 0.0036 & Reject $\mathrm{H}_{0}$
\end{tabular}


European Journal of Accounting, Auditing and Finance Research

Vol.8, No. 7, pp.97-120, July 2020

Published by ECRTD-UK

Print ISSN: 2053-4086(Print), Online ISSN: 2053-4094(Online)

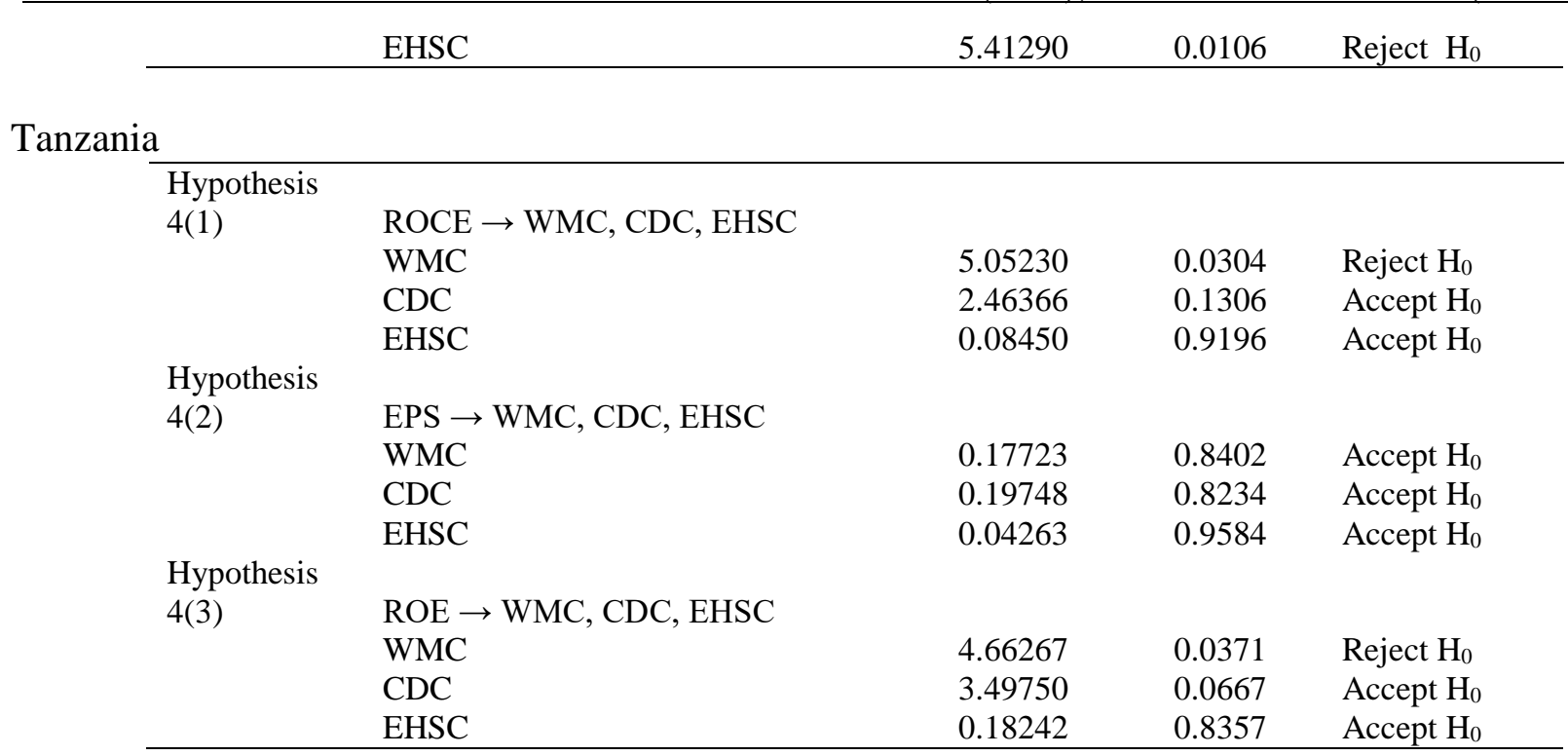

Source: Granger Causality Analysis Output

\section{Hypotheses Decisions}

1. Waste management, community development and employees' health and safety cost have no significant effect on return on capital employed of quoted firms in Sub Saharan Africa. However, there is a positive insignificant relationship between community development, employees' health and safety cost and return on capital employed, while a negative relationship exists between return on capital employed and waste management cost.

2. Waste management, community development and employees' health and safety cost have no significant effect on earnings per share of quoted firms in Sub Saharan Africa. However, Environmental cost is positively but insignificantly related with earnings per share.

3. Waste management, community development and employees' health and safety cost have no significant effect on return on equity of quoted firms in Sub Saharan Africa. Return on equity is positively and insignificantly related with community development, employees' health and safety cost but negatively and insignificantly associated with waste management cost.

4. In South Africa and Nigeria, waste management, community development and employee health and safety costs have insignificant effect on return on capital employed, earnings per share and return on equity. For Ghana, waste management, community development and employee health and safety costs have significant effect on return on capital employed and return on equity while the predictors demonstrated insignificant effect on earnings per share. Only waste management costs in Tanzania has significant effects on return on capital employed and return on equity. 
European Journal of Accounting, Auditing and Finance Research

Vol.8, No. 7, pp.97-120, July 2020

Published by ECRTD-UK

Print ISSN: 2053-4086(Print), Online ISSN: 2053-4094(Online)

\section{DISCUSSION OF FINDINGS}

This study examined the effect of environmental costs on performance of quoted firms in Sub Saharan Africa for a period spanning from 2007 to 2016 with a view to affirming or refuting the nexus between environmental responsibility and performances of firms using evidences from Sub Saharan Africa. After a detailed theoretical review and empirical analyses, the findings were made in line with the research objectives and the hypotheses set and tested. The findings are hereby discussed in line with the objectives of the study.

\section{Objective One}

To determine the effect of waste management, community development and employee health and safety costs on Return on Capital Employed of quoted firms in Sub Saharan Africa.

From the analysis carried out, it was discovered that waste management, community development and employee health and safety costs have no significant effect on return on capital employed. This implies that the amounts of these costs incurred by the firms under study are insignificant to cause a swing on firms' performance measurements. However, researches are anchored on volume of data reported by selected firms and consequently, this may be related to both the amount of costs incurred by the firms and the extent of reporting of costs incurred.

\section{Objective Two}

To explore the effect of waste management, community development and employee health and safety cost on Earnings per share of quoted firms in Sub Saharan Africa.

The study found out that waste management, community development and employee health and safety costs have no significant effect on earnings per share. This suggests that the quoted firms in Sub Saharan Africa have not reasonably engaged in waste management, community development and employee health and safety activities that can result to significant effect on earnings per share. Conversely and contrary to the objective of the study, it was revealed that earnings per share has significant effect on waste management cost of selected firms in Sub Saharan Africa, implying that earnings per shares of selected firms are responsible for changes in waste management costs. The result suggests that selected firms are motivated by improvement in their earnings per share to engage in waste management activities.

\section{Objective Three}

To ascertain the effect of waste management, community development and employee health and safety costs on Return on Equity of quoted firms in Sub Saharan Africa.

The analysis conducted by this study revealed that waste management; community development and employee health and safety costs have no significant effect on return in equity. Again this shows that the amounts of these costs incurred by firms are insignificant to cause a movement on return on equity. Cost classification and volume of data reported in the annual reports of the firms may contribute to lack of significant effect by the predictor variables on return on equity and research will always rely on data reported for analysis. 
European Journal of Accounting, Auditing and Finance Research

Vol.8, No. 7, pp.97-120, July 2020

Published by ECRTD-UK

Print ISSN: 2053-4086(Print), Online ISSN: 2053-4094(Online)

\section{Objective Four}

In each of the four countries studied, to evaluate the respective effect of waste management, community development and employee health and safety costs on Return on Capital Employed, Earnings per Share and Return on Equity of quoted firms in Sub Saharan Africa. This objective consolidates objectives one, two and three for each of the countries.

For South Africa and Nigeria, the study revealed that waste management, community development and employee health and safety costs have no significant effect on return on capital employed, earnings per share and return on equity. This shows that the environmental costs incurred in each of the two countries are not able to cause any movement on the proxies of firm performance. This may be a function of inadequate engagement by firms in these areas of environmental responsibility or inappropriate classification and reporting of data in the reports. Conversely, the study revealed that earnings per share cause movements in waste management costs suggesting that increase in waste management responsibility activities by selected quoted firms in Nigeria is a function of increase in their earnings per share. The result of the study has remained emphatic about the causality on waste management costs by earnings per share both at regional analysis and in Nigeria, thereby a pointer to the selfish behavioural patterns of firms whose decision to engage in environmental remediation, especially waste management activities is influenced by the outcomes of their earnings per share. This is more critical and curious as it affects waste management activities with the endemic health hazards this trend may expose to the entire populace of Sub Saharan Africa and Nigeria in particular. In Ghana, the study revealed that waste management, community development and employee health and safety costs have significant effect on return on capital employed and return on equity but demonstrated insignificant effect on earnings per share. For Tanzania, the result singled out waste management costs and demonstrated significant effects on return on capital employed and return on equity.

Expectedly, the analysis revealed varied outcomes in the four countries covered by the study. Comparatively, better results were revealed in Ghana where waste management, community development and employee health and safety costs showed significant effect on return on capital employed and return on equity. Next to Ghana in terms of better result is Tanzania where waste management costs showed significant effects on return on capital employed and return on equity. These results may suggest comparative improvement in environmental responsibilities, compliances, disclosures and effectiveness of extant enactments applicable in the Ghana and Tanzania on environmental activities (for example, the AKOBEN in Ghana and Environmental Management Act in Tanzania).

Though to the best of the knowledge of this study no similar prior work exists at regional Sub Saharan African level, the outcomes of the study which revealed that environmental costs represented by waste management, community development and employee health and safety costs have no significant effect on firm performance has substantially contradicted some expanded studies from other regions outside Sub Saharan Africa. For example, (Vijfvinkel, \& Bouman, 2011) that studied Dutch and Chinese SMEs with results that indicated significant positive effect; (Gallego-Alvarez et. al., 2015) that studied sample of firms from USA, France, Japan, Italy, Portugal etc and found out firms promote greater environmental behaviour in order to obtain higher financial performance. 
European Journal of Accounting, Auditing and Finance Research

Vol.8, No. 7, pp.97-120, July 2020

Published by ECRTD-UK

Print ISSN: 2053-4086(Print), Online ISSN: 2053-4094(Online)

On specific country perspective, the outcomes of the study have confirmed in some cases and contradicted in others, the results of prior studies in this regard. Findings of the study in South Africa which revealed that environmental costs measured by waste management, community development and employee health and safety costs has no significant effect on firm performance, confirmed studies by (Oberholzer et. al., 2011) while contradicting studies by (Wingard, 2001; Wingard et. al., 2001; Delmas \& Nairn-Birch, 2010). In Nigeria, this study which revealed that environmental cost surrogates(waste management, community development and employee health and safety costs) have no significant effect on firm performance confirmed studies by (Adediran, et. al., 2013; Okoye, et. al., 2017); while it contradicted studies by (Ngekwe, 2008; Oti, et. al., 2012; Peter, et. al. 2012)

In Ghana, where the study revealed a mixed result to the effect that environmental cost measured by waste management, community development and employee health and safety has significant effect on return on capital employed and return on equity but insignificant effect on earnings per share, concurred with study by (Appiah, et. al., 2017). For Tanzania, where waste management costs singly demonstrated significant effect on return on capital employed and return on equity while the rest predictors revealed insignificant effect partly validates (Daniel, 2013; Isanzu, \& Fengju, 2016) in one way or the other.

\section{CONCLUSION}

This study was carried out to empirically find out the effect of environmental costs on performances of quoted firms in Sub Saharan Africa. Environmental engagements that result to environmental costs are not recent in the region. On the one side, it has been argued and posited that environmental responsibility do not engender performances of firms. Contrarily, it is believed that environmental responsibility can stimulate performances of firms. From the study, is has been revealed that environmental costs have no significant effects on performances of quoted firms in regional Sub Saharan Africa, South Africa and Nigeria. The implication is that adequate engagements and disclosure of environmental activities have not taken place in the region. Further, the study revealed that environmental costs have substantial significant effects on performances of quoted firms in Ghana and that waste management costs have substantial significant effects on performances of Tanzania quoted firms. At the regional Sub-Saharan Africa and Nigeria analyses, the study unusually revealed that earnings per share granger cause waste management cost. This is an ugly and selfish trend suggesting that firms in the affected areas will only engage in waste management practices in the current year if their prior years' earnings per share improved.

\section{Recommendations}

In line with the objectives of this study, findings and conclusions were made which facilitate for the following recommendations:

1 .

As a result of weak links revealed by this study between the predictors and dependent variables in Sub Saharan Africa, South Africa and Nigeria suggesting inadequate environmental costs and indulgences by firms on environmental activities in the region 
European Journal of Accounting, Auditing and Finance Research

Vol.8, No. 7, pp.97-120, July 2020

Published by ECRTD-UK

Print ISSN: 2053-4086(Print), Online ISSN: 2053-4094(Online)

and aforementioned countries, there is need for firms in the region, South Africa and Nigeria to do more in this regard.

2 .

Following the strong link demonstrated by the predictors on return on capital employed and return on equity in Ghana and by waste management costs on return on capital employed and return on equity in Tanzania, quoted firms in the aforementioned two countries should improve their engagements in environmental activities to provoke greater effects on the explainable variables.

3.

As a result of the importance of appropriate cost recognition, classification and reporting and disclosure to data for researches, it is hereby recommended that firms in Sub Saharan Africa should design and implement sound cost recognition, classification and reporting framework to ensure appropriate disclosures that will make more data available for research in this regard.

4.

Since costs recognition, classification and disclosure have effects on the available data for researches which in turn affect the result of studies, coupled with the fact that environmental reporting has been largely voluntary in Sub Saharan Africa, it is recommended that governments and professional bodies at regional level should drive firms towards full disclosures by instituting effective and necessary regional enactments and standards that can make recognition and disclosures of environmental activities more compelling or compulsory while civil society organisations can help in sensitization.

\section{References}

Association of Chartered Certified Accountants(2015).Environmental management accounting. Available at http://www. accaglobal.com/an/en/student/exam-supportresources/professional-exams-study-resources/p5/technical-articles/environmentamanagement. $\mathrm{H}$

Adediran, S.A., \& Alade, S.O. (2013). The impact of environmental accounting on corporate performances. European Journal of Business and Management, 5 (23).

Agbiogwu, A. A, Ihendinihu, J.U. \& Okafor, M.C. (2016). The impact of environmental and social costs on performance of Nigerian manufacturing companies. International journal of Economics and Finance 8(9), 173-180.

Al-Matari, E.M., Al-Swidi, A.K. \& Fadzil, F.H.B. (2014). The measurement of firm performance's dimension. Assian Journal of Finance and Accounting, 6(1), 24-49.

Ambec, A. Stefan, P. \& Paul L. (2008). Does it pay to be green? a systematic overview. Academy of Management Perspectives, 22 (4), 45-62.

Amoako, K.O., Lord, B.R. \& Dixon, K.(2016). Sustainability and environmental reports of a mining firm in Ghana: A pilot study. Department of Accounting and Information Systems, University Of Canterbury- Christ church, New Zealand.

Appiah, K., Du, J. \& Boamah, K.B. (2017). The effect of environmental performance on firm performance-evidence from Ghana. British Journal of Interdisciplinary Research, 8(1).

Arafat, Y., Warokka, A. \& Dewi, S.R.(2012). Does environmental performance really matter? A lesson from the debate of environmental disclosure and firm performance. Journal of Organizational Management Studies. 
European Journal of Accounting, Auditing and Finance Research

Vol.8, No. 7, pp.97-120, July 2020

Published by ECRTD-UK

Print ISSN: 2053-4086(Print), Online ISSN: 2053-4094(Online)

Arong, F. E., Ezugwu, C.I. \& Egbere, M.I. (2014). Environmental cost management and profitability of oil sector in Nigeria. Journal of Good governance and Sustainable Development in Africa. 2(2).

Barbu, E., Dumontier, P., Feleag. N \& Feleag L.(2012). Mandatory environmental disclosures by companies complying with IAS/IFRS: The case of France, Germany and the UK. HAL Archieves Available at:https://halshs.archives-ouvertes.fr/halshs-00658409.

Bartolacci, F., Paolini, M. Soverchia, A. \& Zigiotti, E. (2016).Waste management and financial performance: evidence from Italian companies. Management International Conference.

Bassey, E. B., Sunday, O. E., \& Okon, E.E. (2013). The impact of environmental accounting and reporting on organisational performance of selected oil and gas companies in Niger Delta region of Nigeria. Research Journal of Finance and Accounting, 4(3).

Beredugo, S. B. (2014). Environmental accounting and social responsibility disclosure on the earning capacity of Nigerian manufacturing firms. Journal of Economics and Sustainable Development, 5(14).

Betianu, L. (2005). Environmental management accounting - An essential component of business strategy. International Conference on The Impact of European Integration on the National Economy, organized by Faculty of Economics and Business Administration Babe ş Bolyai, University of Cluj Napoca, 277-284..

Daniel, L.N. (2013). The effect of environmental regulation on financial performance in Tanzania: A survey of manufacturing companies quoted on the Dar Es Salam stock exchange. International Journal of Economics and Financial Issues, 3(1), 99-112.

Delmas, M. A., \& Nairn-Birch, N.S. (2010). Is the tail wagging the dog? An empirical analysis on corporate carbon footprints and financial performance. Working paper 6, UCLA Institute of the Environment and Sustainability, Los Angeles.

Delmas, M.A., Nairn-Birch, N.S. and Lim, J.(2015). Dynamics of environmental and financial performance: the case of greenhouse gas emissions. Organization \& Environment, SAGE Publications, 28(4) 374-393.

Demissie, M. Z. (2014). The natural resources course in Sub Sahara African: transparency and international initiatives. Abstract of a Dissertation Submitted to the Graduate School of The University of Southern Mississippi in Partial Fulfilment of the Requirements for the Degree of Doctor of Philosophy

Duke, D. \& Kankpang, F. (2013). Implication of corporate social responsibility for the performance of Nigeria firms. Advances in Management \& Applied Economics, 3(5), 73 87.

Earnhart, D. \& Lizal, B. (2010). The effect of corporate environmental performance on financial outcomes-profit, revenue and costs: Evidence from the Czech transition economy. Department of Economics, University of Kansas.

Filbeck, G., \& Raymond G. (2004). The relationship between the environmental and financial performance of public Utilities. Environmental and Resource Economics, 29,137-154.

Gallego-_Alvarez, I., Segura, L. \& Martínez-Ferrero, J.(2015). Carbon emission reduction: the impact on the financial and operational performance of international companies. Journal of Cleaner Production, 103, 149-159.

Horvathova, E. (2010). Does environmental performance affect financial performance? A metaanalysis. Ecological Economics 70 (1), 52-59. 
European Journal of Accounting, Auditing and Finance Research

Vol.8, No. 7, pp.97-120, July 2020

Published by ECRTD-UK

Print ISSN: 2053-4086(Print), Online ISSN: 2053-4094(Online)

Ifurueze, M.S.K, Etale, L.M \& Bingilar, P.F. (2013). The impact of environmental costs on corporate performance: a study of oil companies in Niger Delta States of Nigeria. Science and Education Centre of North America, (2)2, 1-10.

Isanzu, J. \& Fengju, X. (2016). Impact of corporate social responsibility on firm's financial performance: the Tanzania perspective. Journal on Innovation and Sustainability, 7(1), 18 27.

Makori, D. M. \& Jagongo, A. (2013). Environmental accounting and firm profitability: an empirical analysis of selected firms listed in Bombay stock exchange, India. International Journal of Humanities and social Science, 3 (18).

Moneva, J.M. \& Ortas E.( 2010). Corporate environmental and financial performance: A multivariate approach. Industrial Management and Data Systems 110 (2), 193-210.

Neely, A. (2015). Business performance measurement unifying theories and interpreting practice ( $2^{\text {nd }}$ Ed), NY, USA: Cambridge University Press.

Nyirenda, G., Ngwakwe, C.C. \& Ambe, C.M (2013). Environmental management practices and firm performance in a South African Mining Firm. Managing Global Transition, 11(3), 243-260.

Oba, V. C., Fodio, M. I., \& Soje, B. (2012). The value relevance of environmental responsibility information disclosure in Nigeria. Acta Universitatis Danubius. OEconomica, 8(6), 100113.

Oberholzer, M., \& Prinsloo, T.F. (2011). Estimating the efficiency of sustainable development by South African mining companies. Journal of Human Ecology 36 (3), 179-184.

Ogbe, M.G., (2003). Biodiversity and the oil industry in the Niger Delta: a sensitive environment. Journal of Nigerian Environmental Society 1(1), 95-112.

Ogbe, M.G., (2006). Managing the environmental challenges of the oil and gas industry in the Niger Delta. A paper presented at the Eastern zonal conference of the Institute of Chartered Accountants of Nigeria, held in Port Harcourt, Rivers State, July 26-29.

Okoye, E.I. \& Adeniyi, S.I. (2017). Effects of environmental protection cost on product price in Nigeria: study of brewery industry. Arabian Journal of Business and Management Review (Nigerian Chapter), 4(2), 52-58.

Omodero C. O. \& Ihendinihu J.U. (2016). Impact of environmental and corporate social responsibility accounting on organizational financial performance: evidence from selected listed firms in Nigeria Stock Exchange. Journal of Emerging Trends in Economics and Management Sciences 7(5), 291-306.

Osisioma, Hilda; Nzewi, Hope \& Okoye, Paul (2015). Corporate social responsibility and performance of selected firms in Nigeria. International Journal of Research in Business Management,3(3), 57-68.

Oti, P.A., Effiong, S.A \& Tiesieh, .A.T (2012). Environmental costs and its implication on the return on investment: an evaluation of selected manufacturing companies in Nigeria. Global Journal of Management and Business Research, 12(7).

xPeter A.O.,Sunday A.E. and Tapang A.T,.(2012). Environmental costs and its implication on the returns on investment. Global journal of management and Business Research. 12(7).

Pramanik., A. K., Shil, O. H. \& Das, A. B (2007). Environmental accounting and reporting. Deep publication PVT. Ltd. New Helhi. 
European Journal of Accounting, Auditing and Finance Research

Vol.8, No. 7, pp.97-120, July 2020

Published by ECRTD-UK

Print ISSN: 2053-4086(Print), Online ISSN: 2053-4094(Online)

Richard, P.J., Devinney, T.M., Yip, G.S. \& Johnson, G. (2009). Measuring organizational performance: towards methodological best practice. Journal of Management: Sage Publications, 718-803.

Schaltegger, S., Gibassier, D. \& Zvezdov, D. (2013). Is environmental management accounting a discipline? A bibliometric literature review. Meditari Accountancy Research, 21(1), 4-31.

Singapurwoko, A. \& El-Wahid, M.S.M. (2011). The impact of financial leverage to profitability: Study of non-financial companies listed in Indonesia Stock Exchange. European Journal of Economics, Finance and Administrative Sciences 32, 136-48.

UNEP (2000). Global environmental outlook, policy responses Africa.

United Nations Integrated Environmental and Economic Accounting (2003). Available at http:/unstats.un.org/unsd/envaccounting/seea2003.pdf

Uwuigbe, U \& Olayinka, M.U. (2011). Corporate social and environmental disclosure in Nigeria: A comparative study of the building material and brewery industry. International Journal of Business and Management, 6(2)

Vijfvinkel, S. and Bouman, N. (2011). Environmental sustainability and financial performance of SMEs. EIM Business and Policy Research, the Netherlands. Retrieved from www.entrepreneurship-sme.eu.

Wingard H.C (2001). Financial performance of environmentally responsible South African listed companies. Doctor Commercii(Accounting Sciences) thesis submitted to the faculty of Economic and Management Sciences, University of Pretoria, South Africa.

Wingard, H. C., \& Vorster, Q (2001). Financial performance of environmentally responsible South African listed companies. Meditari Accountancy Research 9 (1): 313-32. 